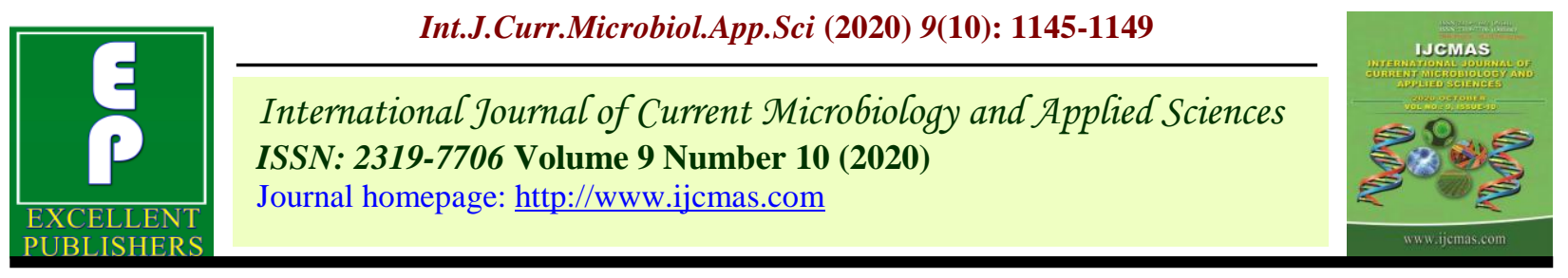

Original Research Article

https://doi.org/10.20546/ijcmas.2020.910.137

\title{
Suitability Assessment of Vegetable Picking Bag for Diversified Activities
}

\author{
Nisha Arya* and Nirmala Yadav \\ Department of Textile and Apparel Designing, I. C. College of Home Science, \\ CCS Haryana Agricultural University, Hisar, India \\ *Corresponding author
}

\begin{tabular}{l} 
K e y w o r d s \\
$\begin{array}{l}\text { Drudgery, Farm } \\
\text { workers, Vegetable } \\
\text { picking, suitability, } \\
\text { Diversified } \\
\text { activities }\end{array}$ \\
\hline Article Info \\
$\begin{array}{l}\text { Accepted: } \\
10 \text { September } 2020 \\
\text { Available Online: } \\
10 \text { October } 2020\end{array}$ \\
\hline
\end{tabular}

Keywords

Drudgery, Farm picking, suitability, Diversified activities

Accepted:

10 September 2020

10 October 2020

\section{A B S T R A C T}

Farm workers are engaged in various agricultural operations like presowing, weeding, picking and post picking. All these tasks are time consuming and become full of drudgery over years. Access to affordable technology reduces drudgery, saves time and increases work efficiency of farm workers. Adoption of such technologies radically changes their life. Vegetable picking is one of the laborious tasks performed by the farm workers at the fields. Efforts have been made to develop user friendly pick bag for vegetable picking which would reduce the drudgery and increase their efficiency. The present study was carried out in pre dominantly vegetable and fruit growing areas namely Sirsa and Fatehabad districts of Haryana with the objective to assess suitability of developed vegetable picking bag for diversified activities on various parameters. Developed bag was found suitable and thus recommended for diversified activities i.e. vegetables (brinjal, okra, guar, chilli), fruits (Kinnow, guava) and flowers (marigold) picking.

\section{Introduction}

Agriculture is the backbone of Indian economy, contributing not only the largest share to the national income but also giving employment to a large number of people. While working in agricultural fields, farm workers engage in various agricultural operations like pre-sowing, weeding, picking and post picking. All these tasks are time consuming and full of drudgery (Gandhi et al., 2012). Also, many farming and allied activities performed by the farm workers involve a lot of physical strain which adversely affects their work efficiency and leads to several types of occupational health hazards like mechanical hazards, chemical hazards, musculoskeletal disorders, environmental hazards, physical hazards, biological hazards etc. These health hazards create serious health problems for the workers in the long run. Incidences of chronic skeletal 
muscular and postural health problem such as strain/sprain, neck pain, joint pain, back pain, hand and leg pain, shoulder pain, chest pain, accidents like cut/wounds, scratches, injury and respiratory diseases such as asthma are indicative of work related health disorders (Chaoudhari et al., 2009).

The health of farm workers is an important factor which adds to agricultural development. Therefore, drudgery reduction measures need to be initiated to avoid occurrence of health hazards among farm workers. In view of this, it was felt that there was an urgent need to make them aware about latest drudgery reducing technologies and motivate them to adopt the same. If appropriate drudgery reducing technologies are made available to the farm workers, it would definitely contribute in reducing their drudgery, increasing their working capability, increasing farm production, resulting in improved quality of life (Sundhesha, 2018).

To overcome the problems faced by the farm workers in the fields, pick bag for vegetable collection was designed and developed for farm workers. Pick bag for vegetable collection was then tested in the fields for diversified activities and was found better than existing method of collection of vegetables, fruits and flowers. It was also found acceptable technology for being user friendly.

Adoption of such technologies can significantly change the lives of farm workers as access to affordable technology reduces drudgery, saves time and increases work efficiency of farm workers. Efforts have been made to develop user friendly vegetable picking bag which would reduce the drudgery and increase the efficiency of farm workers. To assess the suitability of developed Pick bag for vegetable collection, field testing of bag was done on various parameters.

\section{Technical plan}

\section{Designing and development of Pick bag for vegetable collection}

Pick bag for vegetable collection was designed and developed as per the ergonomic assessment to make the pick bag more users friendly. Following are some of the features of Vegetable picking bag:

\section{Length}

Length was kept as per the anthropometric measurements of Haryana women i.e. 72 to $78 \mathrm{~cm}$.

\section{Pockets}

Bottom edges of the pockets were made more curved for smooth movement of the product in the pick bag and pocket was also backed with stiff material i.e. tetron. The pocket opening was placed at 4 inches below the elbow level for convenience during picking activity for ease of movement of hands. Also,

Width of the bag was increased.

Strings were added in front for proper stay of the pockets.

Gathers in front of pocket were added to provide fullness.

\section{Neck line}

Width of neck was kept i.e. $18.5 \mathrm{~cm}$ as per the acromial width so as to avoid pressure on the neck and shoulder point. Shoulder belts forming the neck line were cushioned to make it comfortable for long use.

\section{Suitability assessment}

Field testing of pick bag for vegetable collection was done to assess its suitability on various parameters for diversified activities 
i.e. picking vegetables (brinjal, chilli, summer squash, cabbage, cauliflower, okra and guar); fruits (kinnow, guava) and flower (marigold \& rose) on fifty respondents at Hansi, Hisar, Barwala and Fatehabad. An interview schedule was developed, validity of which was checked by jury of experts. Data were collected by personal interview technique. Suitability assessment was done on five point scale i.e. highly suitable, suitable and somewhat suitable, least suitable and unsuitable scoring 5, 4, 3, 2 and 1, respectively.

\section{Results and Discussion}

Field testing of the vegetable picking bag was done to assess its suitability for diversified activities i.e. vegetable, flower and fruit collection and presented in Table 1-3 and Fig. $1-3$

Suitability assessment of vegetable picking bag for diversified activities

\section{Vegetable collection}

\section{Brinjal}

Vegetable picking bag was assessed to be highly suitable as it was convenient to put on (4.6), was comfortable, appealing, convenient for loading - unloading, functional and also adjudged as good replacement over the existing methods with suitability score 4.4.

\section{Okra}

Pick bag was found as highly suitable for okra picking with reference to the parameters of 'comfortable during wear', 'convenient to put on', 'convenient for loading - unloading', 'appropriate size \& shape',' good replacement over existing methods' with suitability score 4.8 Pick bag was also reported as functional (4.6), 'increase efficiency' (4.6) and appealing (4.4).

\section{Guar}

For guar picking, bag was assessed to be highly suitable as it was comfortable during wear , convenient to put on, load- unload, functional, increase efficiency, good replacement over existing method (4.6). It was also found to be highly suitable with reference to appeal and size and shape (4.4).

\section{Summer squash, cabbage and cauliflower}

Bag was found to be least suitable for picking of summer squash, cabbage \& cauliflower as suitability score regarding various parameters was observed as 1.0. Although, it was found somewhat suitable in terms of appeal and comfort (2.94).

Fig.1 Suitability assessment of pick bag for vegetable collection

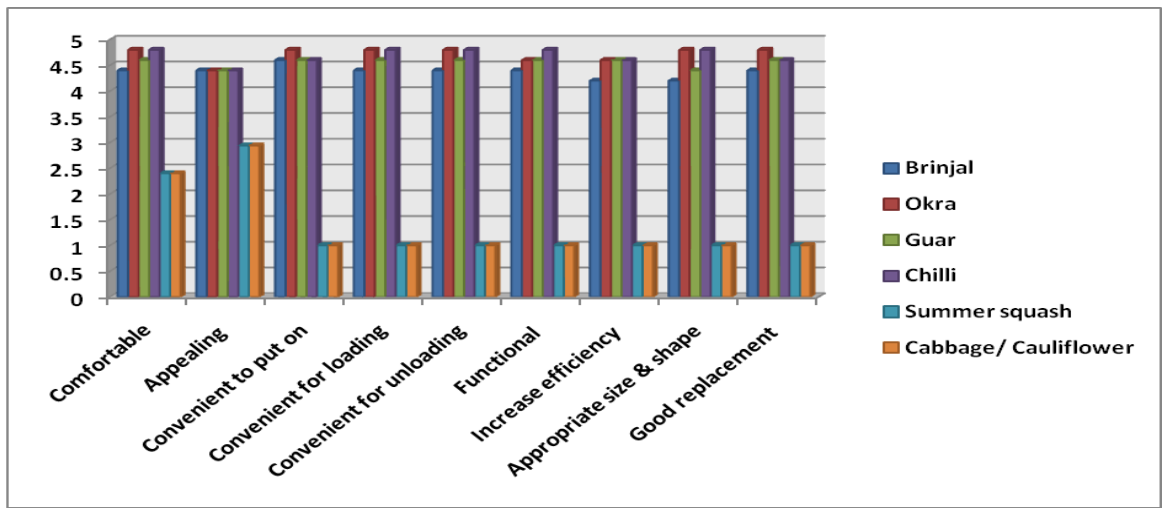


Fig.2 Suitability assessment of vegetable picking bag for fruit collection

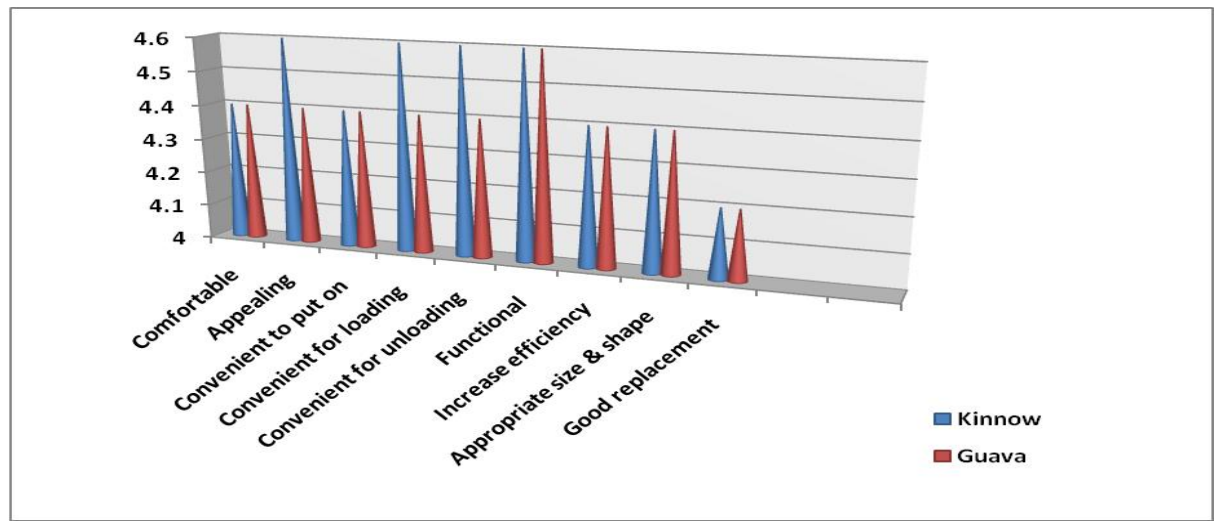

Fig.3 Suitability assessment of pick bag for flower collection

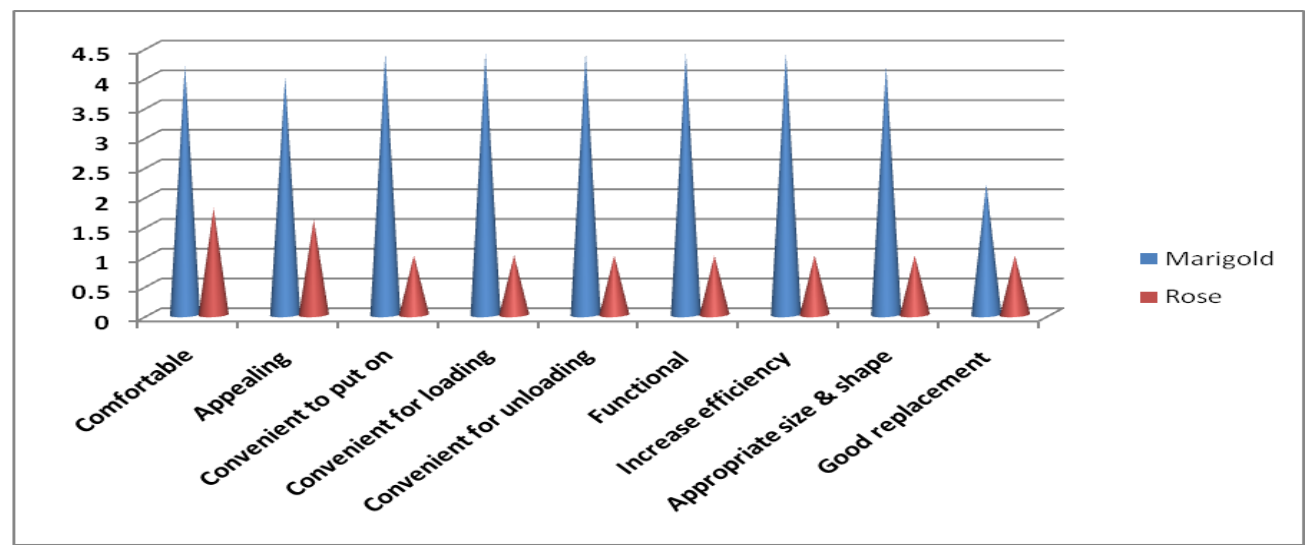

Testing of vegetable picking bag in the fields

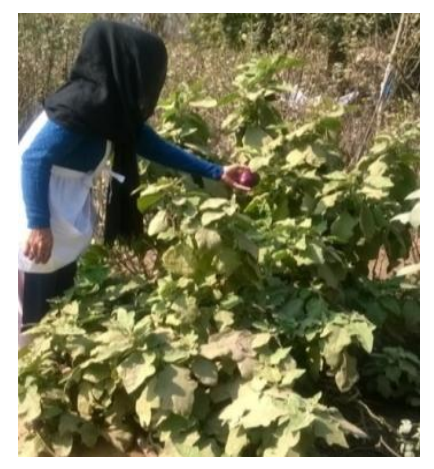

\section{Chilli}

For chilli picking, the bag was assessed as highly suitable with reference to all the suitability parameters with suitability score ranging from 4.4 to 4.8 .

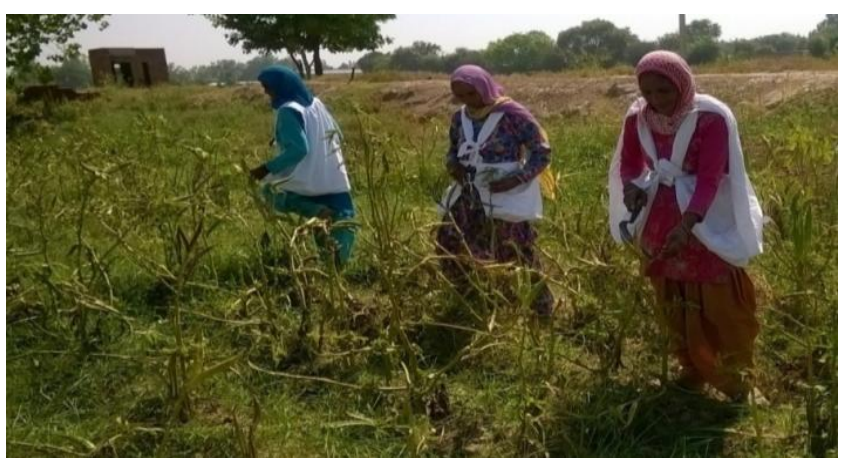

Fruits collection

Vegetable picking bag was assessed as highly suitable for "Kinnow picking" with reference 
to all the suitability parameters as weighted mean score ranged from 4.4 to 4.6 . It was assessed as suitable for the parameter of considering it a good replacement over the existing methods (4.2).

\section{Guava}

Pick bag was found to be highly suitable for picking of guava with reference to suitability parameters of functional, comfortable, appealing, convenient to put on, load- unload, increase efficiency, appropriate size \& shape having Suitability score 4.4 to 4.6 . Bag was assessed as suitable with respect to 'good replacement over existing methods' (4.2).

\section{Flower collection}

\section{Marigold}

Vegetable picking bag was found to be highly suitable with regard of suitability parameters as it was convenient to put on (4.4), convenient for loading - unloading (4.4) and comfort (4.4). It was assessed as suitable with regard to 'increase efficiency' (4.2), appeal (4.2) and functional (3.9). But practically, it was not considered as a good replacement over existing method (2.2)

\section{Rose}

Pick bag was found to be least suitable for "Rose picking" with reference to various suitability parameters.

It was observed that Pick bag for vegetable picking was found to be highly suitable for brinjal, okra, guar, chilli, kinnow and guava.
In conclusion, developed Pick bag for vegetable picking was found suitable and thus recommended for diversified activities i.e. vegetables (brinjal, okra, guar, chilli), fruits (Kinnow, guava) and flowers (marigold) picking.

It seems to be a good initiative towards reduction of drudgery and increasing work efficiency of the worker. Hence, with tireless efforts, it can go a long way in improving quality of life of rural people in general and farm workers in particular.

\section{References}

Chaoudhari M., Singh, S., Rathor, H. and Vyas, R. 2009. Drudgery reduction technologies for women to enhance productivity and safety in agriculture. Conference on drudgery of Women Agriculture and its Management. November 17th to December 7th, Udaipur (Rajasthan): 1-7.

Gandhi, S., Dilbaghi, M., Bimla and Yadav, N. 2012.Drudgery reduction of women using cot bag in cotton picking. Paper published in Book of papers of International Symposium on "Global Cotton Production Technologies vis-àvis Climate Change" at CCS Haryana Agricultural University, Hisar from 1012 October: $353-357$.

Sundhesha, S., Ahlawat, S. and Singh, S. 2018. Awareness and Adoption of Drudgery Reducing Technologies among Farm Women of Dantiwada Taluka. International Journal of Agriculture Sciences. 10(1): 4972-4975.

\section{How to cite this article:}

Nisha Arya and Nirmala Yadav. 2020. Suitability Assessment of Vegetable Picking Bag for Diversified Activities. Int.J.Curr.Microbiol.App.Sci. 9(10): 1145-1149. doi: https://doi.org/10.20546/ijcmas.2020.910.137 